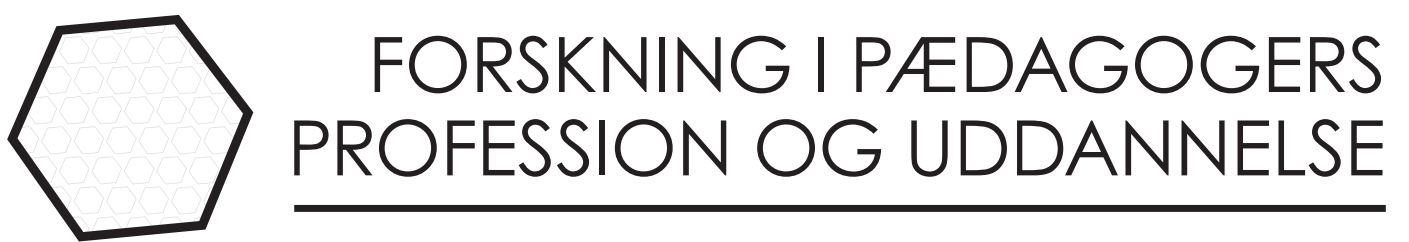

\title{
Gruppe-ekspertise i paedagogik med henblik på omsorgsarbejde
}

\section{Søren Engelsen}

Ph.d., postdoc, Institut for Mennesker og Teknologi, Roskilde Universitet engelsen@ruc.dk 


\section{Resume}

Artiklen argumenterer for, at pædagogisk ekspertise kan tilskrives grupper og ikke kun individer. Hvordan skal vi helt fundamentalt forstå pædagogisk gruppe-ekspertise? Artiklen anlægger et pædagogisk-filosofisk perspektiv på dette spørgsmål. Med et fokus på pædagogisk omsorgsarbejde afklarer den, hvad de fundamentale forudsætninger er for gruppeekspertise. Første del undersøger minimumsbetingelserne for, hvad man kan kalde pædagogisk ekspertise. Idealet om pædagogisk ekspertise må forstås bredt, hvis vi skal fastholde det som et meningsfuldt forbillede for pædagogisk teori og praksis. Artiklen analyserer og kategoriserer væsentlige aspekter af ekspertise i en pædagogisk sammenhæng. Pædagogisk ekspertise må rumme en pluralisme af former for viden og kompetencer, både praktiske, teoretiske, før-refleksive og refleksive, samt adfærdsdispositioner, emotionel opmærksomhed og intellektuelle kapaciteter. Artiklens anden del undersøger de filosofiske betingelser for gruppe-ekspertise og drager nogle vigtige distinktioner. Det argumenteres således, at grupper kan have overlegen viden qua gruppe, som de enkelte medlemmer hver især ikke besidder, og denne viden kan under de rette betingelser udgøre ekspertise. For at anskueliggøre denne forståelse af gruppeekspertise illustrerer artiklen til slut idéen i en sammenhæng af pædagogisk omsorgsarbejde. Her eksemplificeres det, hvordan gruppe-ekspertise i pædagogisk omsorgsarbejde kan bestå af samspillet mellem konstitutive delelementer.

\section{Abstract \\ Group expertise in pedagogy for care work}

The article argues that pedagogical expertise can be attributed to groups and not just individuals. How should we fundamentally understand pedagogical group expertise? The article takes a pedagogical-philosophical perspective on this issue. With a focus on pedagogical care work, it clarifies the fundamental prerequisites for group expertise. The first part examines the minimum conditions for what can be called pedagogical expertise. If we are to maintain it as a meaningful ideal of pedagogical theory and practice, pedagogical expertise must be understood broadly. The article analyzes and categorizes significant aspects of expertise in a pedagogical context. Pedagogical expertise must accommodate a pluralism of knowledge forms and competencies. These include practical, theoretical, pre-reflexive and reflexive competencies, behavioral dispositions, emotional awareness, and intellectual capacities. The second part of the article examines the philosophical conditions of group expertise and draws some important distinctions. Groups can have superior knowledge, which the individual members do not possess individually, and this knowledge can, under the right conditions, constitute expertise. Finally, an example of how constitutive elements of group expertise in pedagogical care work can unfold illustrates the main idea of group expertise in a specific pedagogical care work context. 


\section{Nøgleord}

Pædagogisk ekspertise, gruppe-ekspertise, pædagogisk vidensteori, pædagogisk omsorgsarbejde

Keywords

Pedagogical expertise, group expertise, pedagogical knowledge theory, pedagogical care practice

\section{Introduktion}

Denne artikel giver en filosofisk afklaring af, hvordan vi helt fundamentalt kan give mening til at tilskrive pædagogisk omsorgsekspertise til grupper. Artiklen foregiver ikke at være et fyldestgørende forsvar for gruppeekspertise i pædagogisk omsorgsarbejde, men afklarer de nødvendige minimumsbetingelser for, at vi kan tilskrive ekspertise til en gruppe i omsorgsarbejde. Bidraget hører således til genren pædagogisk filosofi. Det er et forsøg på at give idéen om gruppeekspertise i pædagogisk omsorgsarbejde en filosofisk velovervejet fundering, der teoretisk afklarer fundamentale ontologiske, dvs. værensmæssige, betingelser for pædagogisk gruppeekspertise.

Idéen om gruppe-ekspertise i pædagogisk omsorgsarbejde omfatter et væld af teoretiske problematikker i den filosofiske og pædagogiske forskning. Centrale grundspørgsmål er, hvad ekspertise er (Goldman, 2001), hvad gruppe-ekspertise vil sige, og om det giver mening bogstaveligt at tilskrive ekspertise, endsige viden, til grupper (Klausen, 2015). I pædagogikken har man særlig diskuteret intellektualistiske og praksisorienterede forståelser af ekspertise (Dreyfus \& Dreyfus, 1986; Wackerhausen, 1993). Hertil kommer det relaterede spørgsmål om, hvad der karakteriserer forskellige vidensformer (Dohn \& Klausen, 2020). Særligt relevant er karakteren af knowhow (Ryle, 2000) og tavs viden (Andersen, 2011; Down et al., 2000; Polanyi, 2009).

Artiklen er delt i to hoveddele. I første del præsenterer jeg en række teoretiske bestemmelser, der minimalt knytter sig til pædagogisk ekspertise. I anden del rekonstruerer jeg i lyset heraf konturerne af en positiv teori om grundbetingelserne for pædagogisk gruppe-ekspertise, med særligt henblik på omsorgsarbejde. Fokus i artiklen er vel at mærke ikke en redegørelse for kausale betingelser, men et teoretisk forsøg på en minimal ontologisk bestemmelse af gruppe-ekspertise i omsorgsarbejde, metodisk inspireret af genetisk fænomenologisk analyse (Husserl, 1966; Husserl \& Landgrebe, 1999) og klassisk filosofisk analyse (Overgaard et al., 2013). Artiklens teoretiske pointer illustreres med praktisk orienterede eksempler, dels fiktive, dels indhentet fra en skriftlig korrespondance med en anonym pædagogisk praktiker. Eksemplerne har ikke karakter af struktureret kvalitativ empirisk analyse, men anskueliggør de teoretiske pointer. 


\section{Pcedagogisk praksis-ekspertise}

Antager man, at en person er 'ekspert', ligger visse umiddelbare associationer lige for: Eksperten har stor indsigt i og eksplicit viden om sit fagområdes emner, hun har en overlegen viden i form af flere korrekte overbevisninger om fagområdet end flertallet samt en god evne til at sætte sig ind i nye aspekter af sit fag. Herudover besidder hun et vist overblik over de begrundelser, der er på området (Goldman, 2001, pp. 7-8). Dette begreb om ekspertise kan vi kalde et intellektualistisk ekspertisebegreb, eftersom det beskriver ekspertise primært i termer af intellektuelle kapaciteter.

Det intellektualistiske ekspertise-begreb er dog ikke fyldestgørende: Et væsentligt problem er risikoen for at negligere kvalificerede ikke-intellektuelle evner, der er afgørende for nogle former for ekspertise (Jesse Ralston, 2011). Dette gælder ikke mindst i pædagogikken, hvis faglighed rummer en praktisk dimension, som et rent intellektualistisk ekspertisebegreb ikke indfanger. Denne pointe relaterer delvist til det klassiske skel mellem teori og praksis: Ligesom der er aspekter af det at være ekspert i madlavning, som synes at mangle, hvis man har overlegent kendskab til opskrifter og gode kokkeråd, men ikke kan lave mad, kan ekspertise i pædagogik indebære anvendelsen af pædagogiske principper i praksis. Praksis-evnen følger ikke direkte af, at man har pædagogisk ekspertise i en rent teoretisk betydning.

Der kan imidlertid også være rent praktiske aspekter af pædagogisk ekspertise, som slet ikke forudsætter intellektuel ekspertise (Benner \& Wrubel, 2006). Pædagogisk omsorgsarbejde kan f.eks. ikke reduceres til et spørgsmål om at kunne omsætte teori til praksis. Umiddelbart kan det for nogen måske virke kontra-intuitivt, at det skulle være muligt at have 'ekspertise' på et område uden at have reflekteret og begrebslig forståelse for sit emne. Men flere teoretikere fra forskellige traditioner fremhæver, at mange former for forståelse tager form af før-refleksive evner, der også kan basere sig på ikke-intellektuelle erfaringer. Fænomenologer fremhæver, hvordan før-refleksive erfaringer danner nødvendige betingelser for evnen til at danne distinkte tanker (Dreyfus \& Dreyfus, 1986; Husserl, 1966; Husserl \& Landgrebe, 1999; Merleau-Ponty \& Landes, 2013). Før-refleksive erfaringer kan danne udgangspunkt for kvalificerede praksis-fornemmelser: En erfaren pædagog kan have god fornemmelse for situerede, kontekst-specifikke forhold, f.eks. for hvordan man trøster et barn på empatisk vis, uden nødvendigvis at trække på teori eller reflekterende tanker om emnet. Selv den mest teoretisk, velbelæste pædagog har ikke denne fornemmelse, hvis hun ikke har dannet de relevante praksiserfaringer. Fornemmelserne kan også have karakter af kropsliggjorte, emotionelle erfaringer af det, som i situationen har værdi og betydning for praksis (de Sousa, 1987; Engelsen, 2016, 2018b; Ferran, 2008).

De før-refleksive erfaringer relaterer ofte til besiddelsen af pædagogisk knowhow (Ryle, 2000). Det er muligt at have overlegen viden om, hvordan man facilite- 
rer sanglege for en børnehaveklasse på en nærværende måde uden at være i stand til at forklare eller eksplicitere denne praksis. Knowhow er viden om, hvordan noget forholder sig eller skal gøres. Denne form for viden kan skelnes fra såkaldt propositionel viden, der indebærer eksplicit viden om, at noget forholder sig på en bestemt måde (Audi, 2003; Ryle, 2000). At have pædagogisk knowhow kan også indebære at være tilbøjelig til at gøre bestemte ting under passende omstændigheder, f.eks. positionere sin krop på en bestemt måde i rummet eller at kommunikere i et bestemt tonefald. Pædagogisk knowhow er altså ikke kun et spørgsmål om før-refleksiv erfaring og føling med den pædagogiske situation, men udmønter sig tillige i kvalificerede dispositioner.

Videns-kapaciteten kan også udgøre tavse former for viden, dvs. viden, der går helt 'bag om ryggen' på eksperten - som noget hun ved uden nødvendigvis at have en fokuseret, distinkt bevidsthed om det (Andersen, 2011; Polanyi, 2009; Wackerhausen, 1993). En sådan tavs viden kan have forskellige former:

Tavs viden kan udgøre en viden, der er ubevidst. Pædagogen går ikke nødvendigvis rundt og er bevidst om sine stærke relationskompetencer, men under relevante betingelser 'trigges' hendes bevidsthed om forhold, der skal til for at skabe gode relationer, såsom tryghedsskabende adfærd, god kommunikation osv. Pædagogen er disponeret til at blive bevidst om, hvordan man hensigtsmæssigt danner gode relationer, uden at hun behøver at bruge energi på at være bevidst om disse forhold i alle dele af hendes arbejde. Ubevidst, tavs viden kan forstås som en disposition til at blive bevidstgjort om noget under relevante omstændigheder og til at udvise en bestemt adfærd under passende omstændigheder.

Tavs viden kan også referere til en opmærksomhed i 'periferien' af bevidstheden. Når idrætslæreren ved til perfektion, hvordan reglerne i fodbold er, behøver hun ikke at have dem i fokus, mens hun dømmer kampen. Reglerne er stadig en del af hendes bevidsthed, men ikke i fokus: Tavs viden kan udgøre en form for ikke-fokuseret opmærksomhed på noget, en opmærksomhed der ikke desto mindre er kvalificeret og pålidelig. Netop fordi idrætslærerens viden om reglerne er tavs, formår hun at rette sit fulde fokus på at dømme frispark korrekt og fokusere på de pædagogiske aspekter af holdspillet. Den tavse viden former hendes måde at se fodboldkampen. Den er med-styrende for hendes opmærksomhed og muliggør kompleks, situeret viden om det, der foregår på banen.

Denne pointe relaterer også til, at en ekspert har relativt nemmere end en ikke-ekspert ved at tilegne sig ny praktisk og/eller teoretisk viden om sit felt. Som det fremhæves i fænomenologien (Husserl, 1966; Husserl \& Landgrebe, 1999) såvel som i traditionen fra Polanyi (Andersen, 2011; Polanyi, 2009), hænger tilegnelsesevnen netop tæt sammen med, at tavse erfaringsdannelser 'stilladserer' nye og mere komplekse erfaringsdannelser. For at tage et andet eksempel: Når musiklæreren ikke længere behøver at bekymre sig om at få ro i timen og børnenes opmærksomhed, bliver det muligt for hende at danne nye erfaringer med at få det musikalske samspil til at køre. Lærerens viden om, hvordan hun på relations-kompetent vis håndterer sin lærerrolle som autoritativt forbillede i situ- 
ationen er 'gjort tavs'. Netop derfor kan hun bruge energi på at danne ny og mere kompleks pædagogisk viden i situationen.

\section{Et inkluderende begreb om ekspertise}

Forbinder vi 'pædagogisk ekspertise' med perfektionistiske idealer, der er praktisk umulige at efterleve, kommer vi nemt til at tegne urealistiske, idealiserede billeder af det at være pædagogisk kvalificeret. En tankegang, der i reaktion på den slags bekymringer i stedet sætter umiddelbare praksisoplevelser på en piedestal kan dog være lige så problematisk. Selvom vi begrebsligt kan skelne mellem teoretisk og praktisk ekspertise, kan det til tider være svært og uhensigtsmæssigt at adskille dem skarpt i praksis. Skal vi bevare den pædagogiske ekspert som eksemplarisk, må vi fastholde et meget bredt syn på, hvad der giver mening at kalde 'pædagogisk ekspertise'.

Overordnet må vi anerkende, at pædagogisk ekspertise rummer mange facetter: Den rummer overlegen kvalificeret praksis-kunnen, der kan have før-refleksiv karakter og udgøre tavs viden og forskellige slags praktisk knowhow. Derudover rummer den overlegen propositionel og eksplicit viden samt begrundelses-evner i henhold til pædagogiske principper, der støtter sig til relevante faktuelle forhold og teoretisk indsigt og overblik. Hertil kan man tilføje evnen til at bruge pædagogiske principper i relevante praksissammenhænge og bringe dem i samspil med situeret, kontekst-specifik viden.

Ofte vil den pædagogiske ekspert pendle uproblematisk frem og tilbage mellem at trække på før-refleksive erfaringer og knowhow og trække på eksplicit og reflekteret viden. Som traditionen fra Schön bl.a. har påpeget det (Fien \& Rawling, 1996; Leitch \& Day, 2000; Schön, 2017), er der også vigtige former for praksiskunnen, hvor refleksionen er integreret i selve handlingsprocessen. Dette muliggør en løbende improviserende, reflekterende kvalifikation af praksis. Det er dertil værd at fremhæve, at handlings-ekspertise ofte rummer både en evne til at agere kvalificeret med henblik på længerevarende projekter og langsigtede mål og en evne til at agere kvalificeret i konkrete vanskelige situationer, hvor der kræves handling her og nu. Visse mål kræver således også længerevarende brug af en blanding af både praktiske og teoretiske evner (Winch, 2016, p. 7).

\section{Paedagogisk gruppe-ekspertise}

Skal vi redegøre for, hvordan individer opnår viden, kan vi ikke se bort fra den meningsdannelse, der foregår i intersubjektive processer. Social-epistemologiske og konstruktivistiske idéer har længe floreret om, at vidensdannelse er betinget af sociale processer (Berger \& Luckmann, 1967; Goldman, 1999). Ligesom det gælder idéen om samarbejdende læring (Jensen, 2012), er pointen, om at sociale processer er afgørende for vidensdannelsen, i sig selv ikke kontroversiel i dag. Man må dog skelne den kausale pointe, at individers viden opstår i sociale interakti- 
oner, fra den ontologiske tese, at vi kan tilskrive viden og ekspertise til grupper; der er forskel på, hvad en videns årsager er, og hvad viden er. Det er sidstnævnte, som denne artikel handler om.

Gruppe-viden kan også ontologisk referere til flere ting. Det kan henvise til, at individer kan have fælles velbegrundede mål og tanker om de samme emner, f.eks. fælles pædagogiske mål og en delt strategi om midler til og forhindringer for disse mål. En sådan forståelse er eksempel på såkaldt fælles intentionalitet (Gilbert, 1989): Vi kan som individer, der indgår i fællesskaber, rette vores opmærksomheder på de samme emner og samtidig være opmærksomme på, at vi er fælles herom (Stein, 1989; Zahavi \& Salice, 2017). En anden ontologisk betydning af gruppe-viden, som jeg vil fokusere på her, kan formuleres som tesen, at visse former for viden kun er til i gruppe-sammenhæng. Således mister individerne deres viden, hvis de hver for sig er alene. Dette gør gruppen til det ontologiske grundlag for individernes viden snarere end omvendt (om end en gruppe selvsagt stadig består af individuelle medlemmer).

Idéen om gruppe-ekspertise i pædagogikken relaterer til teorier om distribueret kognition i psykologien (Hutchins, 2004, 2020). Den indebærer idéen om et samarbejdende fællesskab, der arbejder mod fælles pædagogiske mål, og som kun i kraft af samarbejdet besidder en ekspertise, som medlemmerne ellers ikke ville have. Gruppe-ekspertise opstår således i kraft af individers koordinerede, vidende samarbejde, ikke af en ophobning af individers ekspertiser. I henhold til det bredt forståede ekspertise-begreb kan gruppe-ekspertise ligeledes udgøres af overlegen teoretisk viden, praktisk viden eller en kombination.

\section{Arbejdsdeling, bevidsthed og gruppe-viden}

Tesen om gruppers viden og gruppe-ekspertise kan for nogen fremstå filosofisk problematisk, bl.a. fordi man kan forbinde viden med at være bevidst om bestemte ting, og bevidsthed som en overindividuel størrelse forekommer mystisk. Men der er ikke nødvendigvis noget mystisk ved idéen om, at grupper kan have viden (Hager, 2014; Klausen, 2009, 2015). Som jeg tidligere har være inde på, indebærer viden ikke nødvendigvis en konstant bevidsthed om emnerne. Man kan f.eks. besidde viden om inkluderende praksisser i forhold til integrationen af tosprogede i en pædagogisk sammenhæng, uden at man konstant har dette i sin bevidsthed. Snarere refererer viden her til dispositioner - f.eks. til at danne bevidste meninger i overensstemmelse med de realiteter, der relevant knytter sig til emnet, eller til at handle kvalificeret. Vi går kort sagt ikke konstant rundt og er bevidste om alt, hvad vi ved og kan, hvorfor muligheden er åben for at tilskrive grupper viden uden at forudsætte en gruppe-bevidsthed: En gruppe har viden om et emne for så vidt, at dens medlemmer i kraft af samarbejdet er disponerede til at dømme korrekt på pålidelig basis og/eller agere på relevante kvalificerede måder på området, når det er passende. De har som gruppe ekspertise om emnet, hvis deres gruppeviden er overlegen i forhold til gængs viden om emnet. 
Forskellige pædagogiske evner kan være fordelt blandt forskellige gruppemedlemmer og tilsammen bidrage til perspektiver, holdninger og handlinger, der kvalificerer den pædagogiske praksis, på en måde som de enkelte individer ikke ville være i stand til hver især (Hager, 2014; Hutchins, 2020; Klausen, 2015). I samarbejdet opstår der en synergi i kraft af en form for erkendemæssig og handlingskvalificeret arbejdsdeling. Denne består i en fordeling af videnskompetencer, der kombineret udgør gruppens viden og kan udgøre en form for ekspertise, for så vidt den er (eller bliver) overlegen.

\title{
Det vigtige samspil: Videns-gunstige miljøer, falles grundvardier og god kommunikation
}

Gruppeviden forudsætter, at de forskellige kapaciteter kommer i samspil på gunstige måder (jf., Klausen, 2015, p. 825). Som allerede filosoffen Adam Smith havde øje for om arbejdsdeling (om end i en økonomisk sammenhæng), er der en risiko for, at arbejdsfunktioner deles på en måde, hvor sammenhængen mistes, og resultatet bliver det modsatte af ekspertise (Winch, 2016, p. 8). Grundpointen er generel og gælder også i andre komplekse praksissammenhænge, hvis kvalitet afhænger af en sammensætning af forskellige elementer: Bandmedlemmer kan være teknisk dygtige hver især, men det er det velfungerende samspil, der højner bandets niveau. Den gode solo bliver til i kraft af, at de andre instrumenter understøtter den. På samme måde er det kun i kraft af, at pædagogiske medarbejderes forskellige kvalifikationer fungerer i et koordineret samspil, at en pædagogisk gruppe-viden kan eksistere. Fælles kommunikation kan her være afgørende, og denne faciliteres bl.a. af god ledelse.

En pædagog, jeg har være i samtale med om emnet, pointerer om vigtigheden af at have redskaber til at undgå fragmentering:

\begin{abstract}
"Min kollega og jeg er meget forskellige ... men har samme grundlceggende vordiscet. Hvis vi snakker om, hvad vores mål er i vores arbejde med børnene, er det det samme. Vi er enige om, at omgangstonen og omgangsformen skal voere kcerlig og positiv. Vi er enige $i$ de grundloggende pcedagogiske linjer såsom hverdagsrutiner, børnevenlig indretning osv. ... Vi har haft nogle sammenstød igennem de par år, fordi vi er gået forbi hinanden og ikke har kunnet rumme hinandens forskelligheder. Men vi har loert at snakke sammen - vi er blevet bedre til at scette ord på overfor hinanden-hvad der er sucert for os og hvad der er vigtigt for os."
\end{abstract}

Selvom det måske ikke er en nødvendig forudsætning for gruppe-viden i alle sammenhæng (Klausen, 2015), kan fælles værdier, som pædagogen fremhæver det, være en måde at få de forskellige kapaciteter i spil til at supplere hinanden. Værdierne kan institutionaliseres i kraft af fælles pædagogiske retningslinjer, arbejdsrutiner, normer, ritualer, mål og midler. Dette kan også typisk indebære en god fornemmelse af styrker og svagheder gruppemedlemmerne imellem samt en generel agtelse for det enkelte individs værd - som menneskeligt individ, men også i kraft af individets funktioner for gruppens fælles praksis. Fælles værdier 
kan også stadfæstes af en etableret gruppe-identitet, f.eks. en delt faglig stolthed forbundet med at være pædagog og med at bidrage til at fremme de pædagogiske mål i fællesskab. I den velfungerende pædagogiske gruppe har man at gøre med en fælles identitet i kraft af forskellige individer. Disse funktioner kan være ekspliciterede, men også forblive implicitte.

\section{Eł konkret eksempel på paedagogisk gruppe-ekspertise: Omsorgsarbejde i paedagogikken}

Ud fra ovenstående forudsætninger kan et utal af pædagogiske forhold i princippet tænkes som nogle, vi kan tilskrive grupper at have en ekspertise i. Rigtig interessant i praktisk-anvendeligt henseende bliver det imidlertid først, når vi kan eksplicitere betingelserne for forskellige former for pædagogisk gruppe-ekspertise for evt. at fremme dem. Jeg har i min bog Etiske færdigheder i pædagogisk praksis (Engelsen, 2018a) udviklet en teori om de almenmenneskelige færdighedsbetingelser for etisk kunnen i pædagogisk praksis. Jeg forstår, groft sagt, i denne bog pædagogisk, etisk kunnen som ensbetydende med almenkompetencer der i samspil er grundkomponenter for velkvalificeret, pædagogisk omsorgsarbejde. Konturerne af denne teori kan således også bruges som afsæt for en analyse af minimale ontologiske betingelser for pædagogisk omsorgsarbejde. Jeg vil i det følgende eksemplificere, hvordan pædagogisk gruppe-ekspertise kan tage sig ud i en sammenhæng af pædagogisk omsorgsarbejde. Hermed anskueliggør jeg de filosofiske betragtninger om gruppeekspertise.

Teorien om de etiske færdigheder går kort fortalt ud på, at etisk kunnen i pædagogisk praksis er en kompleks, dvs. sammensat, evne til omsorgsarbejde. Denne evne består af forskellige simplere kompetencer i samspil: Ligesom synssansen, lugtesansen, høresansen, smagssansen mv. i samspil udgør vores evne til sanselig perception, gør de etiske almenfærdigheder i samspil os i stand til kvalificeret, pædagogisk omsorgsarbejde. De væsentligste almenfærdigheder er empati, perspektiv-fleksibilitet, selvforståelse og emotionel opmærksomhed (Engelsen, 2018a). Når man besidder disse almenfærdigheder, muliggøres (etisk kvalificeret) pædagogisk omsorgsarbejde. Samspillet imellem dem er helt afgørende: Ligesom synssansen kan korrigere høresansen ("jeg troede jeg hørte postbuddet, men jeg kunne se, at det bare var en kat"), supplerer og korrigerer den ene etiske færdighed den anden, som vi skal se.

Lad mig illustrere med et praksis-eksempel: Vi kan tænke os, at pædagogen John på stuen Mariehønsene i kraft af sin stærke evne til empati bidrager til at give børnene et nærvær, som er afgørende for relationsdannelsen og generelt muliggør en god stemning på stuen, f.eks. når han dagligt hyggelæser med børnene eller eksemplarisk håndterer konflikter. Han har rigtig god emotionel opmærksomhed på børnenes og deres egne perspektiver i nuet - og han får herigennem blik for de gode grunde til at handle på bestemte måder tilknyttet deres unikke børne-perspektiver. Til gengæld er Johns empati ofte ulige fordelt børnene imel- 
lem. Dette er en typisk tendens for empatisk stærke personer, bl.a. fordi vi mennesker generelt har nemmere ved at indgå i empatiske relationer med mennesker, som vi identificerer os med (Bloom, 2016; Prinz, 2009). Ideelt ville John måske selv være opmærksom på sin tendens til en ulige fordeling af opmærksomheden blandt børnene, men virkeligheden er sjældent ideel. John har heldigvis en god kollega i Julie, der er opmærksom på det. Hun har et godt blik for retfærdigheden af at fordele opmærksomheden nogenlunde ligeligt. Julie mestrer perspektiv-fleksibiliteten - f.eks. er hun god til at have fornemmelse for, hvornår det er passende at indtage det bredere perspektiv på arbejdet, og hvornår et koncentreret fokus på det konkrete her og nu er på sin plads. Til gengæld har hun ofte ikke tålmodighed til alt for meget nærvær med børnene. Hun er ikke følelseskold eller u-empatisk, men bruger for meget energi på nærværet og har tendens til at tage arbejdet med hjem, når hun kommer 'for tæt' på børnene. Til gengæld mestrer Julie det større overblik og de mere langsigtede perspektiver på stuen, og hun har fornemmelse for vigtigheden af de forskellige perspektiver. Hun er rigtig god til at prioritere tids- og andre resurser hensigtsmæssigt ud fra de givne arbejdsvilkår, og hun er, modsat John, også teoretisk interesseret. Dette giver hende gode evner til at se generelle mønstre, som ikke alle får øje på. Hun har blik for vigtigheden af ikke at give de 'nemme' børn uretmæssigt større opmærksomhed og negligere andre, eller for den sags skyld bruge alle tidsresurserne på nogle enkelte børn og dermed nedprioritere andre eller gruppen som helhed. Den tredje i gruppen er lederen Tove, der er god til at bemærke arbejdsgruppens og dens medlemmers styrker og svagheder. Hun er opmærksom på ovenstående tendenser hos både John og Julie, og hun kender sine egne kommunikationsevner og evne til at få et team til at samarbejde om fælles projekter. Hun har 'selvforståelse' på gruppens vegne og forsøger med handlingsprocedurer, norm- og værdi-sættelse på gruppens vegne samt kommunikation gennem jævnlige formelle og uformelle møder at være 'limen', der får de forskellige kapaciteter til at hænge sammen og komme i relevante samspil.

Pointen her er, at ingen af disse gruppemedlemmer hver for sig kan siges at være eksperter i pædagogisk omsorgsarbejde. Det er kun i og med samspillet, at vi kan tale om noget sådan på gruppens vegne. Tværtimod vil Johns uhensigtsmæssige tendens til at give nogle børn mere opmærksomhed i mange situationer føre til decideret uretfærdige handlinger, hvis ikke han bliver suppleret af Julies bredere perspektiver og Toves opmærksomhed på gruppens og medlemmernes styrker og svagheder. Står Julies 'helikopter-perspektiv' alene, vil hun til gengæld mangle empatiske nærværs-perspektiver, og Tove mangler tilsvarende nogle afgørende perspektiver, hvis hun er isoleret fra gruppens dynamik, navnlig direkte førstehåndserfaringer med flere af de problematikker, der opstår i det daglige pædagogiske arbejde. Det er i kraft af den synergiske effekt af de tre kollegaers velfungerende samarbejde, at deres evner i samspil kan inkarnere en form for omsorgspædagogisk ekspertise. Denne opstår i og med deres disposition til at sætte deres kompetencer i samspil på de rigtige måder og i de rigtige sammenhæng. 
Når vi tematiserer ekspertise i omsorgsarbejde, kan vi forbinde den med noget, som et individ kan besidde: Vi kan forestille os en person, der besidder yderst veludviklede omsorgsfaglige kompetencer i alle henseender, og som således meningsfuldt kan betegnes som ekspert i pædagogisk omsorgsarbejde. Men som illustreret ovenfor kan vi lige så vel se de afgørende almenfærdigheder som nogle, der snarere end alle at tilhøre et enkelt individ er fordelt blandt medlemmerne af en gruppe. Enkeltmedlemmer mestrer således én eller flere færdigheder bedre end de andre, men færdighedernes styrke-fordeling er nogenlunde fordelt i gruppen medlemmerne imellem. Når dette bliver kombineret med et arbejdsmiljø, der frugtbart tillader disse egenskaber at komme i samspil, muliggør det dermed gruppe-ekspertise i pædagogisk omsorgsarbejde. Hvert enkelte medlem bidrager i kraft af på pålidelig vis at kunne opfange bestemte relevante forhold i den pædagogiske praksis og handle på bestemte måder, der samlet set kvalificerer det pædagogiske arbejde.

\section{Konkluderende og perspektiverende betragtninger}

Man kan argumentere for, at det er at strække begrebet at tale så bredt om 'pædagogisk ekspertise', som jeg har gjort det i det foregående. Vi må f.eks. anerkende, at begrebet 'ekspertise' nok for mange kan give umiddelbare intellektualistiske og individualistiske associationer. Men den reflekterede og eksplicit begrundende bevidsthed er ikke i alle sammenhænge hverken nødvendig eller tilstrækkelig betingelse for fagligt kvalificeret pædagogik. Det afgørende for pædagogisk praksis er, at vi fastholder blikket for en pluralisme af både teoretiske og ikke-teoretiske måder, hvorpå vi kvalificerer det pædagogiske arbejde. Derudover er det vigtigt hverken at overintellektualisere praksis-ekspertise eller at fortabe sig i over-skeptisk anti-intellektualisme, såfremt begrebet skal spille en vigtig rolle som ideal i pædagogisk arbejde. Vi må generelt være påpasselige i vores anvendelse af 'eksperten' som autoritativt ideal, hvis det skal have en praksis-relevans i pædagogik. Begrebet må inkludere en nuanceret forståelse af overlegen handlingskompetence såvel som stærk teoretisk kompetence indenfor et felt. I pædagogisk sammenhæng er det med denne meget brede forståelse vigtigt at slå fast, at ekspertise kan komme i mange former, og man kan have mere eller mindre ekspertise indenfor et felt. Pædagogiske fagfolk skal således ikke nødvendigvis alle gå rundt og være fag-eksperter; det er et ideal, der ikke skal føre til individualistisk perfektionisme. Også af denne grund er gruppe-perspektivet på pædagogisk ekspertise relevant.

Vi kan forbedre den pædagogiske praksis ved at være opmærksom på, hvad der udgør gruppeekspertise i forskellige pædagogiske sammenhæng. Vi kan med fordel rette fokus på, i hvor høj grad relevante kvalificerende færdigheder er hensigtsmæssigt fordelt gruppemedlemmer imellem, men også i hvor høj grad disse kommer i spil på relevante måder, så de rent faktisk supplerer hinanden og styrker 
ekspertisen i samspil. Samspils-pointen er måske allermest presserende at rette fokus på i praksissammenhæng. Hvis Julies empatiske underskud eksempelvis ikke bliver suppleret af Johns stærke empati, og hvis Johns tendens til uretfærdig fordelt opmærksomhed til børnene bliver til tunnelsyn og ikke korrigeret af Julies helikopterblik, kan vi ikke tilskrive omsorgs-ekspertise til gruppen - tværtimod. Denne udfordring påkalder sig et større fokus på, dels at kortlægge de minimale forudsætninger for forskellige former for pædagogisk ekspertise, som jeg har givet et eksempel på i denne artikel, dels et fokus på hvordan man i grupper rent faktisk får de relevante videnskapaciteter til at supplere hinanden i et frugtbart samspil.

Blikket for at fordele kvalificerende kompetencer og videnskapaciteter, og bringe dem i samspil, er relevant for eksempelvis sammensætningen af medarbejdere i teams. Det er også væsentligt i forhold til pædagogisk uddannelse og opkvalificering samt planlægning af arbejdsprocedurer, fælles værdier og fagidentiteter. Gruppeorienteringen kan meget vel være en mere realistisk tilgang til at opnå praksis-ekspertise i pædagogisk arbejde end det individualistiske perspektiv, eftersom det enkelte individ ikke behøver at være overlegen og kunne det hele.

De sociale rammer for interaktionerne er i dette perspektiv afgørende for pædagogisk ekspertise, og vi må spørge til, om de kulturelle, sociale og økonomiske rammer er til stede, der understøtter og giver plads til de kvalificerende og menings-skabende videnskapaciteter. For så vidt de pædagogiske praktikere hver især besidder relevant viden, der med fordel kan blive til ekspertise i relevante synergiske samarbejder, sørges der da for, at disse rent faktisk kommer i de afgørende samspil, så de kan korrigere og supplere hinanden på en hensigtsmæssig måde? Er der f.eks. regelmæssige rutiner og relevante kommunikationskanaler i form af informative samtaler, effektive journalsystemer mv., hvor relevante inputs formidles? Eller står visse normer, rutiner og dagsordener tværtimod i vejen for samspillet?

Med muligheden for pædagogisk gruppe-ekspertise kan vi med fordel erstatte individualiserede forståelser af pædagogiske bestræbelser og problemer med et større fokus på sociale processer, herunder et forstærket blik på arbejdsdelingens fordele, også i erkendemæssige og handlingskvalificerende henseender. En faldgrube, vi i denne sammenhæng skal undgå, er at fokusset på den videns-konstituerende arbejdsdeling bliver ensbetydende med at reducere pædagogers arbejde til snævert definerede arbejdsfunktioner. Gruppe-viden og gruppe-ekspertise er afhængig af relevante arbejdsdelinger, men vi må samtidig have blik for helheden af arbejdet og ikke mindst de mere eksistentielle aspekter af arbejdslivet for gruppen og den enkelte pædagog. 


\section{Litteratur}

Andersen, R. (2011). Tavs viden og praktik. En diskussion af Polanyis teori om tavs viden i forhold til praktik $i$ sygeplejeuddannelsen og $i$ pcedagoguddannelsen. https://www.ucviden.dk/portal/ da/publications/tavs-viden-og-praktik(6fd30642-71d4-40f4-925f-c6c505a210b3).html

Audi, R. (2003). Epistemology. A Contemporary Introduction to the Theory of Knowledge (2nd ed.). Routledge.

Benner, P., \& Wrubel, J. (2006). Omsorgens betydning $i$ sygepleje. MUNKSGAARD.

Berger, P. L., \& Luckmann, T. (1967). The Social Construction of Reality: A Treatise in the Sociology of Knowledge. Ancher.

Bloom, P. (2016). Against Empathy. The Case for Rational Compassion. HarperCollins Publishers. de Sousa, R. (1987). The Rationality of Emotion. MIT Press.

Dohn, N. B., \& Klausen, S. H. (2020). Situativity of different forms of knowledge. In N. B. Dohn, S. B. Hansen, \& J. J. Hansen (Eds.), Designing for Situated Knowledge Transformation (pp. 23-38). Routledge. https://doi.org/10.4324/9780429275692-2

Down, J., Sternberg, R. J., \& Horvath, J. A. (2000). Tacit Knowledge in Professional Practice: Researcher and Practitioner Perspectives. Administrative Science Quarterly, 45(1), 170. https:// doi.org/10.2307/2666987

Dreyfus, S. E., \& Dreyfus, H. L. (1986). Mind over Machine. Free Press.

Engelsen, S. (2016). Emotioners (u)nytte. En fænomenologisk analyse af emotioner i praktisk rationalitet. Akademisk Kvarter, 14, 25-38.

Engelsen, S. (2018a). Etiske foerdigheder i pcedagogisk praksis. Dafolo.

Engelsen, S. (2018b). Feeling value. A systematic phenomenological account of the original mode of presentation of value. In R. K. B. Parker \& I. Quepons (Eds.), New Yearbook for Phenomenology and Phenomenological Philosophy, Issue om Phenomenology of Emotions (pp. 231-247). Routledge.

Ferran, Í. V. (2008). Die Emotionen. Gefühle in der realistischen Phänomenologie. In Philosophische Anthropologie (Vol. 6). Akademie Verlag.

Fien, J., \& Rawling, R. (1996). Reflective Practice: A Case Study of Professional Development for Environmental Education. The Journal of Environmental Education, 27(3), 11-20. https://doi. org/10.1080/00958964.1996.9941462

Gilbert, M. (1989). On social facts. Routledge.

Goldman, A. (1999). Knowledge in a Social World. OUP.

Goldman, A. (2001). Experts: Which Ones Should You Trust? Philosophy and Phenomenological Research, LXIII(1).

Hager, P. (2014). Practice and Group Learning. Educational Philosohy and Theory, 46(6), 569-583.

Husserl, E. (1966). Analysen zur passiven Synthesis. Aus Vorlesungs- und Forschungsmanuskripten, 1918-1926. Husserliana 11 (M. Fleischer (ed.)). Martinus Nijhoff.

Husserl, E., \& Landgrebe, R. und herausgegeben von L. (1999). Erfahrung und Urteil. Untersuchungen zur Genealogie der Logik (7th ed.). Meiner Felix Verlag GmbH.

Hutchins, E. (2004). The social organization of distributed cognition. In L. B. Resnick, J. M. Levine, \& S. D. Teasley (Eds.), Perspectives on socially shared cognition. (pp. 283-307). American Psychological Association. https://doi.org/10.1037/10096-012

Hutchins, E. (2020). Cognition in the Wild. In Cognition in the Wild. MIT. https://doi.org/10.7551/ mitpress/1881.001.0001

Jensen, A. H. (2012). Perspektiver på cooperative learning - at samarbejde om loering. Dafolo.

Jesse Ralston, S. (2011). A More practical pedagogical ideal: Searching for a criterion of deweyan growth. Educational Theory, 61(3), 351-364. https://doi.org/10.1111/j.1741-5446.2011.00408.x

Klausen, S. H. (2009). Kollektiv viden og læring - myte og realitet. In S. H. Klausen \& M. Paulsen (Eds.), Filosofiske perspektiver på kollektiv loering (pp. 15-39). Aalborg Universitetsforlag.

Klausen, S. H. (2015). Group knowledge: a real-world approach. Synthese, 192(3), 813-839. https:// doi.org/10.1007/s11229-014-0589-9 
Leitch, R., \& Day, C. (2000). Action research and reflective practice: towards a holistic view. Educational Action Research, 8(1), 179-193. https://doi.org/10.1080/09650790000200108

Merleau-Ponty, M., \& Landes, D. A. (2013). Phenomenology of perception. In Phenomenology of Perception (2nd ed.). Routledge. https://doi.org/10.4324/9780203720714

Overgaard, S., Gilbert, P., \& Burwood, S. (2013). An Introduction to Metaphilosophy. Cambridge University Press.

Polanyi, M. (2009). The Tacit Dimension (Reissue edition). University Of Chicago Press.

Prinz, J. J. (2009). The Emotional Construction of Morals. Oxford University Press.

Ryle, G. (2000). The Concept of Mind. University Of Chicago Press.

Schön, D. A. (2017). The reflective practitioner: How professionals think in action. In The Reflective Practitioner: How Professionals Think in Action. Basic Books. https://doi. org/10.4324/9781315237473

Stein, E. (1989). On The Problem of Sympathy (3rd ed.). ICS Publications.

Wackerhausen, S. (1993). Tavs viden og pædagogik. Dansk Pcedagogisk Tidsskrift, 4, 190-201.

Winch, C. (2016). Education and Broad Concepts of Agency. In D. Simpson \& D. Beckett (Eds.), Ekspertise, Pedagogy and Practice. Routledge.

Zahavi, D., \& Salice, A. (2017). Phenomenology of the we: Stein, Walther, Gurwitsch. In J. Kiverstein (Ed.), The Routledge Handbook of Philosophy of the Social Mind (pp. 515-527). Routledge. 